\title{
ПАВЛОВНІЯ ДЛЯ ЦЕЛЮЛОЗНО-ПАПЕРОВОЇ ПРОМИСЛОВОСТІ
}

\author{
А.М. Денисенко, С.Ю. Яценко, Р.І. Черьопкіна \\ Національний технічний університет Украйни \\ «Київський політехнічний інститут ім. Ігоря Сікорського» \\ пр. Перемоги, 37, Київ, 03056, Україна \\ e-mail: anna.denysenko.7796@gmail.com
}

Ріст цивілізованих форм побуту неминуче призводить до розширеного споживання картонно-паперової продукції, які необхідні для потреб різного призначення.

Для їх виготовлення використовують волокнисті напівфабрикати від деревної маси до целюлози, які отримують, в основному, з хвойних і листяних порід деревини. Тобто, цивілізація людства, в деякій мірі, залежить від наявності деревини зараз.

На жаль, запаси хвойної деревини у всьому світі швидко скорочуються, що створює їх дефіцит на ринку. В силу різних обставин, останнім часом листяні породи деревини стали більше розглядати в якості сировини целюлозно-паперових матеріалів. Особливо різкий ривок зроблено у Бразилії та Індонезії, де створено умови для вирощування евкаліпту та отримання 3 нього волокнистих напівфабрикатів високої якості. Нині саме ці країни є основними постачальниками целюлози для багатьох підприємств Європи та Америки з виробництва паперу та картону [1, 2, 3].

Однак, природні ресурси, в тому числі деревна сировина, все більше піддаються інтенсивній експлуатації. Але відновленню лісів все ще приділяється недостатньо уваги у порівнянні з їх вирубуванням.

В умовах природного лісовідновлення деревина досягає технічної спілості, тобто коли іiі можна використовувати у різних промислових цілях, в залежності від кліматичних умов, породи, грунтів та інших факторів лише через 50 - 70 років та навіть більше, наприклад, для північних широт. Тому багатьма вченими було розвинуто напрямок прискореного вирощування деревини, основним критерієм яких є суттєво більший приріст у порівнянні із місцевими видами і більший у нових умовах вирощування у порівнянні із природніми. До порід деревини, які швидко ростуть відносяться такі, що у віці від 5 до 25 років досягають технічної спілості придатної для промислового перероблення з річним приростом приблизно від $15 \mathrm{~m}^{3} /$ га і вище [1]. Найбільш вивченими для плантаційного культивування порід деревини можна віднести тополю, осику, березу, сосну, евкаліпт та інші $[1,3,4]$.

Однак, промисловості потрібні величезні об'єми деревини сьогодні і вже, тому пошук джерел сировини з коротких оборотом вирубування ведеться постійно і великих обертів набирає вирощування різних видів павловнії. Ця деревина відома давно як декоративне дерево. Усі види надзвичайно легко адаптуються до навколишнього середовища, як з точки зору кліматичних змін, так і варіації грунтів [5].

Павловнія (лат. Paulównia), або Ада́мове дерево - рід рослин сімейства Paulowniaceae походить з Китаю та складається з 6 - 17 видів дерев, які швидко ростуть $[6,7]$. 
Іноземними вченими показано, що деревина павловнії має велику комерційну цінність для виготовлення меблів, музичних інструментів, паперу, біопалива, упаковки, текстилю та іiі використання в хімічній промисловості $[5,6]$.

3 наукових джерел відомо, що павловнію використовують в екологічних цілях, тобто рослини здатні вбирати з грунту і води промислові забруднювачі, пропускати їх через свою судинну систему, затримувати їх в собі, що допомагає очищати і відновлювати навколишнє середовище $[6,10]$.

Павловнія відноситься до м'яких порід деревини, які мають найбільшу швидкість росту у висоту та у ширину в світі. За деякими відомостями за один рік рослина виростає від $1,5-2 \mathrm{M}$ до 3,5 м $[6,9]$. За оптимальних умов вирощування за 5 років може досягати висоти $15-20$ м і використовуватися в якості повноцінної сировини [6].

Таблиця 1.

Ріст павловнії у порівнянні з іншими видами швидкорослих дерев $[8,9]$

\begin{tabular}{|l|c|c|c|}
\hline \multicolumn{1}{|c|}{ Вид дерева } & Річний приріст, м & $\begin{array}{c}\text { Висота трирічного } \\
\text { дерева, м }\end{array}$ & $\begin{array}{c}\text { Максимальна висота } \\
\text { дорослого дерева, м }\end{array}$ \\
\hline Павловнія & $3-5$ & $10,5-15,5$ & $15-20$ \\
\hline Тополя чорна & $2,5-3,5$ & $9-12$ & $20-25$ \\
\hline Евкаліпт червоний & $2-2,5$ & $6-9$ & $10-15$ \\
\hline Верба гідридна & $1,5-4$ & $7,5-12$ & $15-25$ \\
\hline
\end{tabular}

Нині відомо як мінімум 6 видів павловнії: P. Elongate, P. Tormentosa, P. Fortunei, P. Fargesii, P. Giabrata, P. Taiwaniania [6].

Для стимуляції і більш швидкого росту та формуванню рівного стовбура у перший рік після посадки проводять технічне зрізання нарощеної маси. На третій рік можна зрізати деревину, яка досягає висоти 9 м і дає приріст від 50 т/га/рік маси. На п'ятий рік деревина досягає розмірів ділової та після іï зрізання рослина здатна регенерувати новий пагін. 31 га можна отримати 400 м $^{3}$ маси кругляка. Щільність сухої деревини складає $300-310$ кг $/ \mathrm{m}^{3}$ [6].

За сприятливих умов вирощування павловнії плантація з 2000 дерев на га може давати до 150 - 300 т деревини на рік лише через 5 - 7 років після ії посадки [10].

В Україні значного поширення вирощування павловнії набуває вид Paulownia Clone in Vitro $112 ®$. Це штучно виведене та клоноване дерево, яке здатне культивуватися в екстремальних умовах від $-25 /-27$ до $+45{ }^{\circ} \mathrm{C}$. Клон занесено до реєстру в 2007 році в Інституті Видів Рослин (Plant Variety Office, офіційний орган СC). Розроблено цей клон було в університеті КастиліїЛа-Манчі в Іспанії і вважається таким, що має найінтенсивніший приріст деревини [6, 11].

Метою роботи є визначення хімічного складу Paulownia Clone in Vitro 112® однорічної 3 метою використання для отримання волокнистих напівфабрикатів для виготовлення паперу та картону.

Дослідженням піддавали павловнію однорічну, вирощену у Любашівському районі, Одещини. Зовнішній вигляд однорічних зразків павловнії наведено на рисунку 1. 


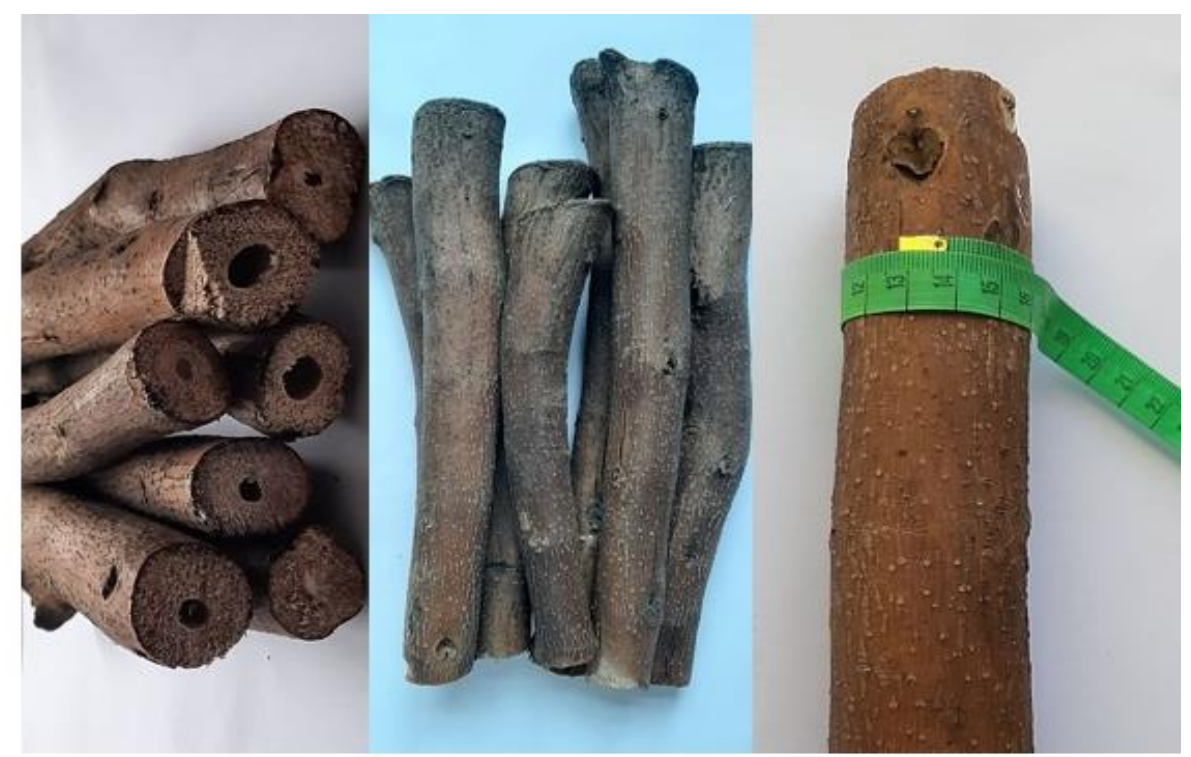

Рисунок. Зовнішній вигляд однорічних зразків Paulownia Clone in Vitro 112®

Особливістю однорічних зразків є наявність пустот у центрі стовбура (замість серцевини), які знаходяться на відрізках між центрами формування листків. Діаметр стовбура на висоті 30 -45 см досягає $11-13$ см.

Для визначення хімічного складу павловнії використовували тирсу, яку отримували в результаті пиляння стовбура ручною пилкою. Визначення целюлози проводили азотнокислим методом, лігніну - методом Классона в модифікації Комарова, СЖВ - спирто-бензольною сумішшю, зольність - методом спалювання, а також визначали речовини, що екстрагуються гарячою водою та розчином лугу за стандартними методиками [12].

Отримані дані хімічного складу наведено в таблиці 2.

\section{Хімічний склад павловнії Paulownia Clone in Vitro 112® у порівнянні із листяними породами деревини}

\begin{tabular}{|l|c|c|c|c|}
\hline Сировина & $\begin{array}{c}\text { Paulownia Clone } \\
\text { in Vitro 112® }\end{array}$ & Павловнія [7] & Сосна [12] & Береза [12] \\
\hline Целюлоза, \% & 45,29 & 50,55 & 47,0 & 41,0 \\
\hline Лігнін, \% & 23,40 & 21,36 & 27,5 & 21,0 \\
\hline Холоцелюлоза, \% & 70,72 & - & - & - \\
\hline $\begin{array}{l}\text { Геміцелюлози, } \\
\text { (пентозани) \% }\end{array}$ & - & $(13,6)$ & 10,4 & 28,0 \\
\hline Екстракція $\mathrm{H}_{2} \mathrm{O}, \%$ & 7,22 & - & 6,7 & 2,2 \\
\hline Екстракція $\mathrm{NaOH,} \mathrm{\%}$ & 26,47 & - & 19,4 & 11,2 \\
\hline СЖВ, \% & 1,35 & - & 3,4 & 1,8 \\
\hline Зола, \% & 0,92 & 0,49 & 0,2 & 0,47 \\
\hline
\end{tabular}

Як видно із наведених в табл. 2 даних, вміст основних компонентів павловнії - вуглеводної частини наближений до хвойних порід деревини, але з вищими значеннями, ніж у листяних. Щодо лігніну, то його вміст у павловнії на рівні з листяними породами, але нижчий ніж у 
хвойних порід, що в подальшому буде визначати технологічні параметри процесу делігніфікації. Вміст СЖВ, екстрактивних речовин, золи наближений до хвойних порід деревини.

На основі аналізу літературних джерел показано перспективність вирощування павловнії 3 отриманням ділової деревини за 5 - 7 років для потреб промисловості.

Виходячи 3 отриманих даних хімічного складу Paulownia Clone in Vitro 112®, що підтверджується літературними джерелами, вона близька до хвойних порід деревини, але 3 нижчим вмістом лігніну, що дозволить спрощувати технологічний процес делігніфікації в ході отримання волокнистих напівфабрикатів.

\section{Література:}

1. Гелес И.С. Древесное сырьё - стратегическая основа и резерв цивилизации. Петрозаводск: Карельский научный центр РАН, 2007. - 499 с.

2. Эвкалиптовая бумага. Електронний ресурс. - Режим доступу: https://rodikon.ru/evkaliptovaya-bumaga.html.

3. Использование целлюлозы из эвкалиптовой древесины в бумажном производстве / Экспресс-инф. Зарубежный опыт. Целлюлоза, бумага и картон. М.: ВНИПИЭИлеспром. 1989. Вып. 5. С. 17-21.

4. Hanssens W.J.H. Plants for the future / Pulp, paper and board. London. NewYork. 1987. Pp. $115-119$.

5. Chhandak Basu, Nirmal Joshee, Tigran Gezalian, Brajesh Nanda Vaidya, Asada Satidkit, Homa Hemmati, Zachary David Perry. Cross-species PCR and field studies on Paulownia elongata: A potential bioenergy crop / Bioethanol. 2015. № 2. Pp. 12-23.

6. Описание. Paulownia Group Ukraine. Електронний ресурс. - Режим доступу: www.paulowniagroup.com.ua.

7. О павловнии. Применение и свойства. Електронний ресурс. - Режим доступу: https://paulownia.pro/ru/paulownia/.

8. Мацкевич О.В., Філіпова Л.М., Мацкевич В.В., Андрієвський В.В. Павловнія: науковопрактичний посібник: Біла Церква: БНАУ: 2019. - 80 с.

9. Juan Carlos Garcia, Minerva Ana Maria Zamudio, Antonio Perez, Hugo Eduardo De Alva, Francisco Lopez. Paulownia as a raw material for the production of pulp by soda-anthraquinone cooking with or without previous autohydrolysis. 2011.

10. Дерево будущего - павловния. Електронний ресурс. - Режим доступу: www.paulownia.bq.

11. Оболенская А.В., Ельницкая 3.П., Леонович А.А. Лабораторные работы по химии древесины и целлюлозы. М.: Экология, 1991. - 321 с.

12. Примаков С.П., Барбаш В.А. Технологія паперу і картону. Навч. посібник / Друге видання, переробл. - Київ: ЕКМО, 2008. - 425 с. 